\title{
Brackenridgea (Ochnaceae) in the Philippines, with notes on foliar nickel hyperaccumulation in the genus
}

\author{
E.S. Fernando ${ }^{1}$, D.N. Celadiña ${ }^{2}$, D.N. Tandang ${ }^{3}$, \\ E.P. Lillo ${ }^{4}, \&$ M.O. Quimado ${ }^{1}$ \\ ${ }^{1}$ Department of Forest Biological Sciences, College of Forestry and \\ Natural Resources, The University of the Philippines - \\ Los Baños, College, 4031 Laguna, Philippines \\ esfernando@up.edu.ph \\ ${ }^{2}$ Department of Forestry, Western Philippines University, \\ Aborlan, Palawan, Philippines \\ ${ }^{3}$ Philippine National Herbarium and Botany Division, National Museum \\ of the Philippines, Padre Burgos St., Manila, Philippines \\ ${ }^{4}$ Department of Forestry, Cebu Technological University, \\ Argao, Cebu, Philippines
}

\begin{abstract}
The genus Brackenridgea (Ochnaceae) in the Philippines is revised. Recent field surveys have provided new locality records and ecological and morphological data to distinguish the three Philippine taxa; all are recognised at species level. The new combination, Brackenridgea mindanaensis (Merr.) Fernando is made. Two names are lectotypified and a second step neotypification is made for one name. Foliar nickel hyperaccumulation is confirmed for all Philippine species.
\end{abstract}

Keywords. Brackenridgea fascicularis, Brackenridgea foxworthyi, Brackenridgea mindanaensis, ultramafic

\section{Introduction}

Brackenridgea A.Gray (Ochnaceae) includes 12 species of shrubs and trees occurring in Africa and Madagascar, the Andaman Islands, southern Thailand, Peninsular Malaysia, Singapore, Sumatra, Borneo, Sulawesi, the Philippines, New Guinea, NE Australia, and Fiji (Kanis, 1968, 1971; Schatz, 2001; Callmander et al., 2010). It is one of the smaller genera of Ochnaceae, a mainly woody pantropical family of about 500 species in 27 genera, with the highest species richness in the Neotropics (Schneider et al., 2014) and lowest in Southeast Asia (Kanis, 1968).

There are two sections in Brackenridgea as circumscribed by Kanis (1968, 1971): Brackenridgea sect. Brackenridgea - flowers all opening simultaneously, the corolla actinomorphic, usually white and 5-merous, stamens up to 10, arranged in a single whorl, and carpels 5; and Brackenridgea sect. Notochnella (Tiegh.) Kanis flowers opening successively, the corolla zygomorphic, usually 'yellow', and with 5-7(-10) petals, numerous stamens arranged in more than one whorl, and carpels 5-10.

In the Philippines, two species have hitherto been recognised (Kanis 1968, 1971; Pelser et al., 2011 onwards), viz. Brackenridgea fascicularis (Blanco) Fern.- 
Vill. (Brackenridgea sect. Notochnella) and Brackenridgea palustris Bartell. (Brackenridgea sect. Brackenridgea). Between these two species, three subspecies are recorded in the Philippines: Brackenridgea palustris subsp. foxworthyi (Elmer) Kanis, B. fascicularis subsp. fascicularis and B. fascicularis subsp. mindanaensis (Merr.) Kanis. Brackenridgea palustris subsp. foxworthyi is known, thus far, only from the central and southern parts of Palawan Island. Brackenridgea fascicularis subsp. fascicularis, until recently, was known only from the central and southern provinces of Luzon Island and on the smaller islands of Catanduanes and Sibuyan. Brackenridgea fascicularis subsp. mindanaensis is restricted only to the northeastern part of Mindanao Island.

In Brackenridgea palustris at least two subspecies, including Brackenridgea palustris subsp. foxworthyi from Palawan, Philippines and Brackenridgea palustris Bartell. subsp. kjellbergii Kanis from Sulawesi, Indonesia have earlier been reported to hyperaccumulate the metal nickel (Baker et al., 1992). More than 700 species throughout the world have been reported as metal hyperaccumulators; about 500 of these, from 52 angiosperm families, hyperaccumulate the metal nickel (Reeves et al., 2017). The term 'hyperaccumulation' is used to describe accumulation of metals (e.g., nickel) to $>1,000 \mu \mathrm{g} \mathrm{g}^{1}$ in dry leaf tissue of plants growing in their natural habitats (Brooks et al., 1977; Reeves, 1992; Van der Ent et al., 2012).

The 15 nickel hyperaccumulators previously reported from the Philippines, in addition to Ochnaceae (Baker et al., 1992), belong to the families Chrysobalanaceae, Salicaceae, and Myrtaceae (Fernando et al., 2013), Dichapetalaceae (Baker et al., 1992), Meliaceae (Baker et al., 1992), Phyllanthaceae (Baker et al., 1992; Hoffmann et al., 2003; Fernando et al., 2013; Gotera et al., 2014; Quimado et al., 2015), and Violaceae (Baker et al., 1992; Fernando et al., 2014). The nickel hyperaccumulator species in these families generally occur in forests on ultramafic soils often characterised as having high concentrations of heavy metals and having low fertility (low in essential elements such as N and P) (Baker et al., 1992; Fernando et al., 2008), many areas of which are currently subjected to mining for metals such as nickel and chromium.

As part of our field surveys of the metallophyte flora of the Philippines and associated nickel hyperaccumulators (Fernando et al., 2013, 2014; Quimado et al., 2015; Ata et al., 2016), we collected leaf samples for elemental analysis and voucher specimens of Brackenridgea. These have revealed new locality records and also provided significant ecological and morphological data to better distinguish the Philippine taxa in the genus. In this paper, we review the ecology and taxonomy of Philippine Brackenridgea and present our data on foliar nickel hyperaccumulation in all three taxa. We recognise all three taxa at species level, which requires one new combination which is formally established here. A key to the Philippine species of Brackenridgea is also presented.

\section{Materials and methods}

All our voucher specimens of new material collected (Tables 1 and 2; see also under Specimens examined) are deposited in the Forestry Herbarium (LBC), Museum 


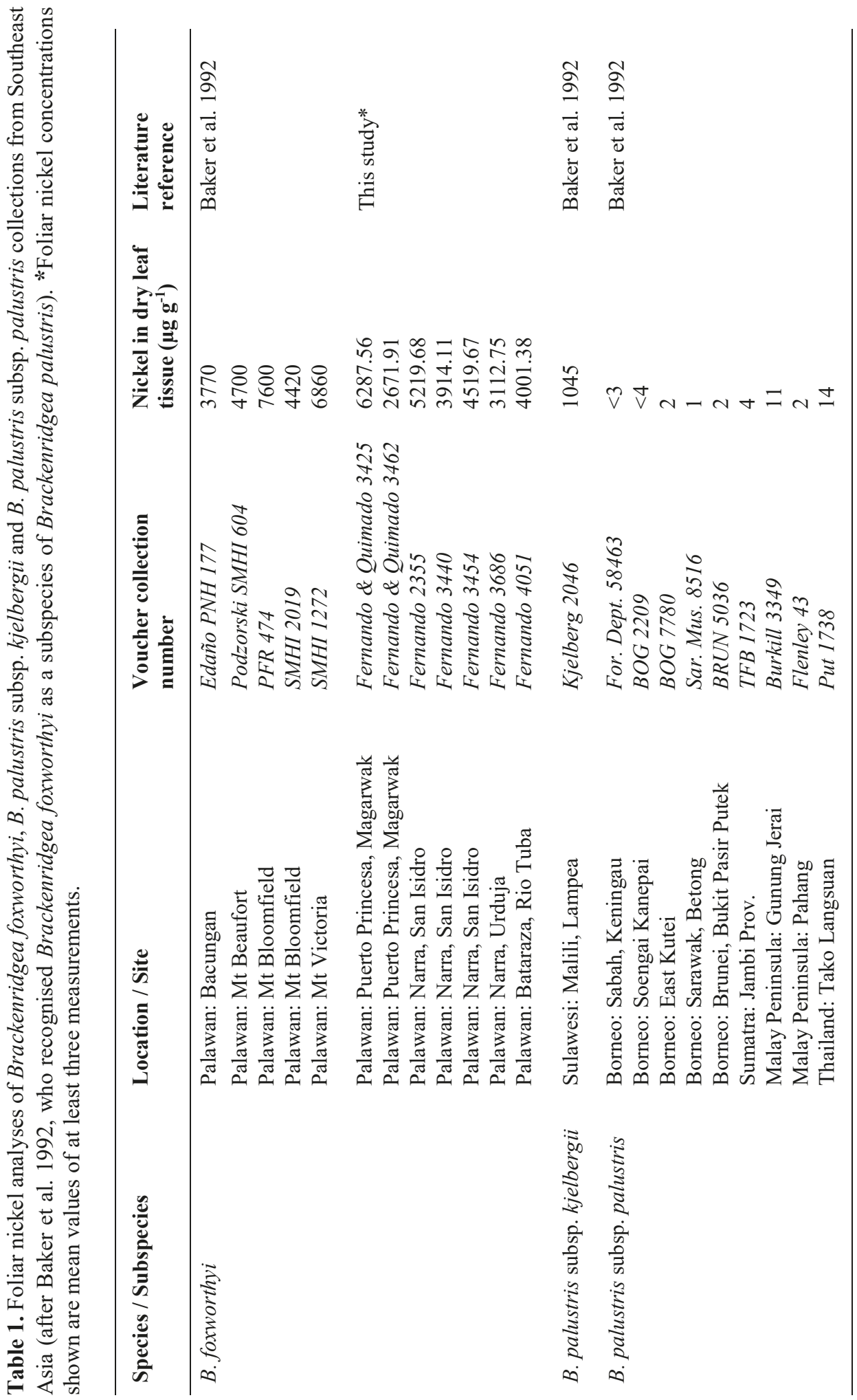


Table 2. Foliar nickel analyses of Brackenridgea fascicularis and Brackenridgea mindanaensis (formerly Brackenridgea fascicularis subsp. mindanaensis) collections from the Philippines. Foliar nickel concentrations shown are mean values of at least three measurements.

\begin{tabular}{|c|c|c|c|}
\hline Species & Location / Site & $\begin{array}{l}\text { Voucher collection } \\
\text { number }\end{array}$ & $\begin{array}{l}\text { Nickel in } \\
\text { dry leaf } \\
\text { tissue } \\
\left(\mu g^{-1}\right)\end{array}$ \\
\hline \multirow[t]{9}{*}{ B. fascicularis } & $\begin{array}{l}\text { Luzon: Aurora Prov., } \\
\text { Dingalan }\end{array}$ & Jacobs 7617 (PNH) & $<100$ \\
\hline & $\begin{array}{l}\text { Luzon: Quezon Prov., } \\
\text { Infanta }\end{array}$ & Fernando 3887 & $<100$ \\
\hline & Samar: Salcedo & Fernando 3925 & 388.86 \\
\hline & Dinagat: Loreto, Malinao & $\begin{array}{l}\text { Fernando \& Breganza } \\
3384\end{array}$ & 1026.63 \\
\hline & Dinagat: Loreto, Balitbiton & Fernando 4143 & 1999.02 \\
\hline & $\begin{array}{l}\text { Dinagat: Loreto, Mt } \\
\text { Kambinliw }\end{array}$ & Lillo 1830 & 830.11 \\
\hline & Dinagat: Tubajon & Fernando 4092 & 3514.00 \\
\hline & Dinagat: Libjo & Fernando 4093 & 4488.52 \\
\hline & Dinagat: Libjo & Lillo 229 & 1196.72 \\
\hline \multirow[t]{3}{*}{ B. mindanaensis } & \multirow{3}{*}{$\begin{array}{l}\text { Mindanao: Surigao del } \\
\text { Norte }\end{array}$} & Fernando 3139 & 3114.16 \\
\hline & & Fernando 3230 & 1545.86 \\
\hline & & Fernando 3764 & 2830.95 \\
\hline
\end{tabular}

of Natural History, University of the Philippines - Los Baños and in the Philippine National Herbarium (PNH), Manila. We also examined additional specimens at BO, CAHUP, CLP, LBC, PNH, PUH, and images of type specimens of Southeast Asian and Philippine Brackenridgea available online at A, GH, K, L, MO, NA, NY, P, U, and US. All photographs shown here were taken in the field in the natural habitats of the species. Risk of extinction assessments follow the IUCN Categories and Criteria (IUCN, 2012) and the Guidelines for Using the IUCN Red List Categories and Criteria (IUCN Standards and Petitions Subcommittee, 2017).

Initial screening for nickel accumulation in the field was done on leaf samples washed in distilled water, crushed with mortar and pestle, and then tested with filter paper previously impregnated with $1 \%$ of the nickel-specific colourimetric reagent, dimethylglyoxime (DMG), dissolved in 95\% ethanol (Baker et al., 1992; Reeves et al., 1996, 1999). High concentration of nickel in the leaves is indicated by the formation a pink or magenta colour. Leaf samples of each plant sampled were also collected and subsequently processed in the laboratory for standard elemental analyses for nickel 
(Ni) by atomic absorption spectrophotometer (AAS). The methodology generally follows that described by Reeves et al. (1996) and in our earlier papers (Fernando et al., 2014; Quimado et al., 2015).

\section{Results and discussion}

\section{Ecology and geographical distribution}

The Palawan Botanical Expedition in 1984 (Podzorski, 1985) yielded collections of Brackenridgea palustris subsp. foxworthyi from several new localities, including Mt Bloomfield, part of the Ulugan Bay ultramafic complex in central Palawan (Proctor et al., 2000), and the Mt Victoria Range in the south. Podzorski (1985) recorded this taxon up to $590 \mathrm{~m}$ elevation on Mt Victoria. The University of Illinois at Chicago Philippine National Herbarium (UIC-PNH) also had a series of short expeditions from 1988 until 1995 (Soejarto, 1989; Soejarto et al., 1996) throughout Palawan, including Irawan Valley and the Mt Victoria Range, among others. We also collected this species from these same localities, and in addition from Magarwak, near Puerto Princesa, and in the far south of the island near Rio Tuba in the Bataraza area. All of the herbarium specimen collections of Brackenridgea palustris subsp. foxworthyi, including the new ones and those cited by Kanis (1968), are only from ultramafic sites. This taxon has only been recorded on ultramafic soils in Palawan. These ultramafic sites generally have high concentrations of heavy metals such as $\mathrm{Co}, \mathrm{Cr}, \mathrm{Fe}$ and Ni (Proctor 1992, 2003; Galey et al., 2017).

Additional collections of Brackenridgea fascicularis subsp. fascicularis from many sites were made in the 1990s, especially by the Philippine Plant Inventory (PPI) Project of the National Museum Philippines / Philippine National Herbarium, in association with the Bernice P. Bishop Museum, Hawaii and later with the Botanical Research Institute, Texas (Stone, 1991; Sohmer, 1996). Previously known only from lowland evergreen rain forests on normal soils, this taxon has now also been collected from ultramafic soils on Sibuyan and our own collections from the islands of Samar, Dinagat, and Mindanao.

The small tree Brackenridgea fascicularis subsp. mindanaensis is rather uncommon and has not been collected elsewhere except from a small area of northeastern Mindanao near its type locality - 'along streams at low altitudes at the iron deposit on the northeast coast' (Merrill, 1920). The only specimens of this taxon after the type material (Ramos \& Pascasio BS 34479) was collected in April 1919 are our own collections from within a currently active nickel mining site in about the same area.

In summary, two of the three taxa of Philippine Brackenridgea, B. palustris subsp. foxworthyi (restricted to Palawan Island) and B. fascicularis subsp. mindanaensis (restricted to Mindanao Island) are, thus far, known only from ultramafic habitats that correspond to the geographical distribution of ophiolite and ophiolite complexes or ultramafic outcrops in the Philippines (Baker et al., 1992; Yumul et al., 2003). The third, Brackenridgea fascicularis subsp. fascicularis, is more widespread in distribution, 
occurring on both ultramafic and non-ultramafic soils at several sites and on islands of the Philippines from Luzon in the north to Mindanao in the south (Fig. 1).

Nickel hyperaccumulation in Brackenridgea

Analysis of foliar tissues of all three Philippine taxa of Brackenridgea revealed them to be nickel hyperaccumulators (Tables 1 and 2). Baker et al. (1992) showed that the three subspecies in Brackenridgea palustris as recognised by Kanis $(1968,1971)$ differ in $\mathrm{Ni}$ accumulation. Leaf samples of Brackenridgea palustris subsp. palustris from herbarium specimens collected in Borneo, Sumatra, Malay Peninsula, and Thailand contained only trace amounts of nickel (Baker et al., 1992; Table 1). Brackenridgea palustris subsp. kjellbergii Kanis from Sulawesi, on the other hand, had more than $1000 \mu \mathrm{g} \mathrm{g}^{-1}$ and B. palustris subsp. foxworthyi from Palawan had 3770-7600 $\mu \mathrm{g} \mathrm{g}^{-1}$ $\mathrm{Ni}$ in dry leaf tissue (Baker et al., 1992; Table 1). Our own samples of Brackenridgea palustris subsp. foxworthyi also showed high concentrations (2671-6287 $\mu \mathrm{g} \mathrm{g}^{-1}$ ) of foliar Ni (Table 1).

In Brackenridgea fascicularis subsp. fascicularis, foliar $\mathrm{Ni}$ accumulation varied from $<100 \mu \mathrm{g} \mathrm{g}^{-1}$ for plants growing on non-ultramafic soils up to $>4000 \mu \mathrm{g}$ $\mathrm{g}^{-1}$ for those growing on ultramafic soils (Table 2). Brackenridgea fascicularis subsp. mindanaensis, on the other hand, had 1545-3114 $\mu \mathrm{g} \mathrm{g}^{-1}$ of foliar Ni. In both these taxa, $\mathrm{Ni}$ hyperaccumulation is reported here for the first time.

\section{Taxonomy}

Data on nickel hyperaccumulation, coupled with the morphological, ecological, and geographical distinction between the three subspecies support raising them to the level of species, which are described and discussed below.

\section{Key to the Philippine Species of Brackenridgea}

1a. Flowers all opening simultaneously; cymes sessile (restricted to Palawan Island) 2. B. foxworthyi

1b. Flowers open successively; cymes pedunculate 2

2a. Cyme peduncle 2-5 mm long; flowers 5-merous, corolla cream-white, stamens 20(45); juvenile fruits (drupelets) light green; tree to $6 \mathrm{~m}$ tall or more, with dense crown; leaf margins entire, only rarely partially denticulate (Luzon, Polillo, Catanduanes, Sibuyan, Samar, Dinagat, Mindanao) 1. B. fascicularis

2b. Cyme peduncle 5-10(-20) mm long; flowers 4-merous, corolla white or light pink, stamens $8(-10)$; juvenile (drupelets) fruits pinkish; small tree, usually not more than $5 \mathrm{~m}$ tall, with lax crown; leaf margins always denticulate (restricted to Mindanao Island) 3. B. mindanaensis 


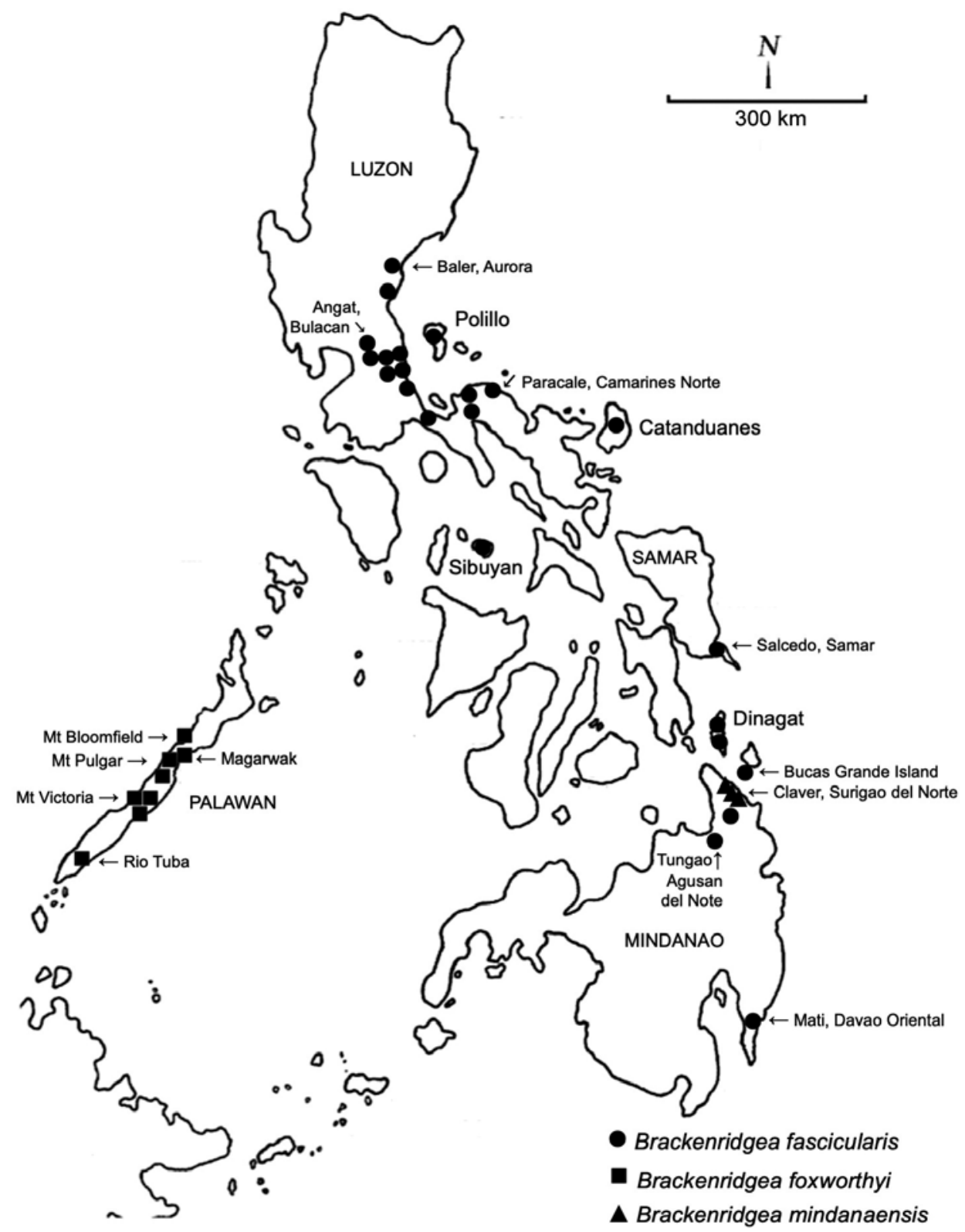

Fig. 1. Distribution of Brackenridgea in the Philippines. B. fascicularis (Blanco) Fern.-Vill. $(\bullet)$; B. foxworthyi (Elmer) Furtado (-); and B. mindanaensis (Merr.) Fernando (ム).

\section{Taxonomic descriptions}

1. Brackenridgea fascicularis (Blanco) Fern.-Vill., Fl. Filip. Nov. App. 40 (1880); Kanis, Blumea 16: 44 (1968); Kanis, Fl. Males. ser. 1, Spermat. 7: 104 (1971). Ochna fascicularis Blanco, Fl. Filip. ed. 2: 245 (1845). - Notochnella fascicularis (Blanco) Tiegh., Bull. Mus. Hist. Nat. (Paris) 8: 549 (1902). - TYPE: Philippines, 
Luzon Island, Bulacan Prov., Angat, s.d., Vidal 1023 (neotype L [L0012441], first step designated by Kanis, Blumea 16: 44 (1968), second step designated here; isoneotype A [A00062712]). (Fig. 2).

Tree up to 6-18(-25) $\mathrm{m}$ tall; stem 10-30(-45) $\mathrm{cm}$ dbh, with dense crown. Leaves simple, alternately arranged; lamina elliptic, (7-)10-13(-17) $\times(2-) 3-4(-5) \mathrm{cm}$, base acute to obtuse or slightly rounded, apex acute to acuminate, margins generally entire, only very rarely partially denticulate; petiole 4-7 mm long. Inflorescence terminal, composed of several many-flowered shortened cymes, up to 15-flowered; rachis of inflorescence 1-2.5 cm long; cyme peduncle 2 $-5 \mathrm{~mm}$ long. Flowers opening successively, 5-merous; pedicel 1-3 cm, sometimes longer in fruit; sepals elliptic to obovate, $6-8 \times 3-4 \mathrm{~mm}$, white, turning red in fruit; petals obovate to obovatelanceolate, $6-8 \times 2.5-4.5 \mathrm{~mm}$, cream-white; stamens $20(-45)$; anthers basifixed, 2-3 $\times 0.4 \mathrm{~mm}$, filaments $1.5-2.5 \mathrm{~mm}$ long; ovary of 8-10 carpels, smooth and glossy, style 4.5-5 mm long. Fruit (drupelet) green when young, becoming red, then glossy black when fully ripe, $5-7 \times 5-6 \mathrm{~mm}$.

Distribution and ecology. Endemic to the Philippines. Luzon (Zambales, Aurora, Quezon, Rizal, Laguna, Camarines Norte, Albay), Polillo, Catanduanes, Sibuyan, Samar (Eastern Samar), Dinagat, and Mindanao (Agusan del Norte, Surigao del Norte). This species is a 'facultative metallophyte' (Lambinon \& Auquier, 1963) or an 'ultramafic facultative' species (Van der Ent et al., 2014), occurring on both ultramafic and non-ultramafic soils at 60-850 m elevation. There is photographic evidence of the occurrence of this species near Socorro on Bucas Grande Island [PhytoImages DOL 130048, 137021, 137068, 137157, 137165, 137186, 137199] and near Mati in Davao Oriental Province, Mindanao Island [PhytoImages DOL 115504, 116543, 116559] (Pelser et al., 2011 onwards).

\section{Local names. Bitas, malakiting-kíting.}

Provisional IUCN conservation assessment. Using GeoCAT (Bachman et al., 2011; http://geocat.kew.org/) an Extent of Occurrence (EOO) of 225,204 km² was calculated, although this includes a very large area of ocean, which qualifies it for the Category of Least Concern (LC). The Area of Occupancy (AOO) was estimated at $184 \mathrm{~km}^{2}$, which qualifies it for the Category of Endangered (EN) as it has also been observed to be in decline in number of locations due to habitat loss and degradation. However, as the population is not known to be severely fragmented as yet and it is known from more than 10 locations, it is assessed here as Near Threatened (NT) following IUCN (2012) and the Guidelines for Using the IUCN Red List Categories and Criteria (IUCN Standards and Petitions Subcommittee, 2017).

Specimens examined. PHILIPPINES: Luzon Island: Aurora Prov., Baler, Dicasalarin, 21 Oct 2009, Tandang s.n. (PNH); ibidem, 24 Dec 2017, Fernando \& Breganza 4420 (LBC); Dingalan, 300-400 m, 11 Mar 1968, Jacobs 7617 (L [L.2390732] image seen, LBC, PNH); ibidem, 700- 


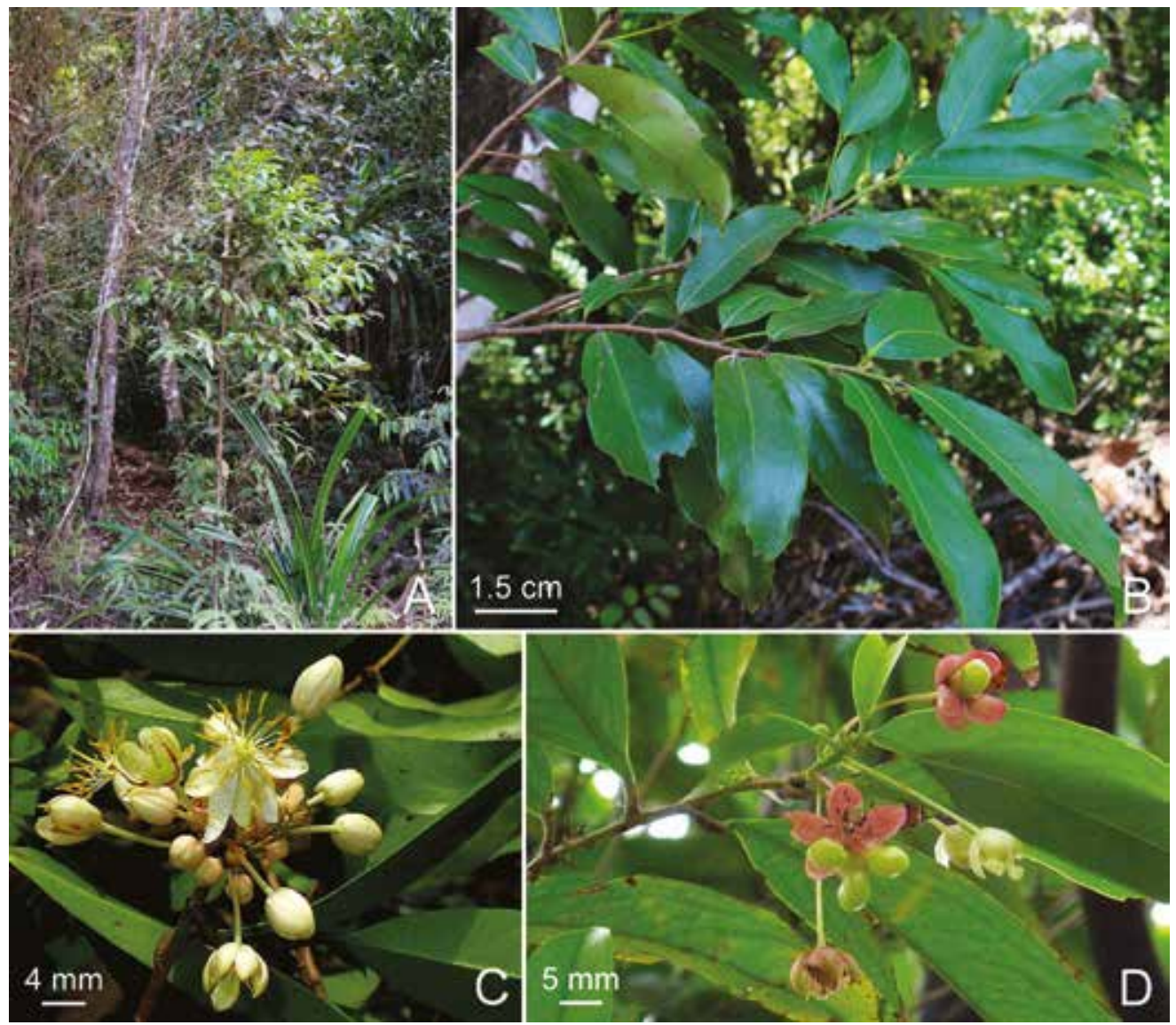

Fig. 2. Brackenridgea fascicularis (Blanco) Fern.-Vill. A. Juvenile tree. B. Branch showing leaf arrangement. C. Twig with inflorescence showing white flowers which open successively. D. Greenish juvenile fruits (drupelets) with red-pinkish calyx. A from Fernando 4092 (LBC); B from Fernando 4096 (LBC); C from Tandang s.n. (PNH); D from Fernando 3887 (LBC). (Photos: A, B, \& D, E.S. Fernando; C, D.N. Tandang).

850 m, 13 Mar 1968, Jacobs 7716 (L [L.2390733] image seen, LBC, PNH); Rizal Prov., San Isidro, 12 Mar 1915, Merrill Species Blancoanae 857 (L [L.2390729], US [US00689132] images seen); ibidem, Mar 1915, Merrill Species Blancoanae 916 (L [L.239072?], US [US00689133] images seen); ibidem, Pililla, Jun 1907, Ramos BS 3296 (L [L.2390727, image seen]; ibidem, Boso-boso, Feb 1907, Ramos BS 2119 (L [L.2390726, image seen]; ibidem, exact locality not known, 6 May 1905, Ahern coll. FB 3077 (L [L.2390731] image seen]; ibidem, Jul 1905, Ahern coll. FB 3174 (L [L.2390730] image seen]); Laguna Prov., Siniloan, U.P. Land Grant, 240 m, 22 Jun 1970, Francia 329 (PUH), 280 m, 25 Mar 1971, Francia 690 (PUH); ibidem, 260 m, 28 Jun 1972, Divino 1234 (PUH); ibidem, Paete, 400 m, 1 Apr 1996, Co 4656 (PUH); ibidem, San Antonio, Jun 1912, Ramos BS 14925 (L [L.2390725] image seen); ibidem, exact locality not known, 300 m, 8 Aug 1956, Lagrimas s.n. (PNH); Quezon Prov., Atimonan, Quezon National Park, 350 m, 17 Mar 1996, Castro et al. PPI 22259 (L [L.2390568] image seen, PNH); ibidem, 300 m, 11 Oct 1970, Barbon 75 (LBC); ibidem, Infanta, along the Marikina-Infanta Road, 600 
m, 30 Nov 2015, Fernando 3887 (LBC); ibidem, Real, 360 m, 4 May 1971, Rojo 122 (CLP, L [L.2390723] image seen); ibidem, Tagkawayan, Brgy. Bagong Silang, 17 Sep 1993, Barbon et al. PPI 12300 (L [L.4149519] image seen, PNH); Camarines Norte Prov., Paracale, Vidal 692 (L [L.2390724] image seen); ibidem, Makahadok, 6 Feb 1950, Rivera 8 (LBC, PNH); ibidem, Basud, 250 m, 26 Dec 1958, Zabala LBC 3383 (LBC); Camarines Sur Prov., exact locality not known, 12 Mar 1937, Villanueva LBC 023 (LBC). Polillo Island: Burdeos, Salolo, 21 Aug 1991, Barbon et al. PPI 1991 (L [L.4163967] image seen, PNH). Catanduanes Island: Tagamasuso, Brgy. Sagrada, Viga, 750 m, 16 Nov 1996, Reynoso \& Majaducon PPI 27090 (L [L.4149521] image seen, PNH). Sibuyan Island: Magdiwang, Barrio Hawasan, Ating River, 28 May 1992, Stone et al. PPI 6770 (L [L.4149511] image seen, PNH); Karningawan Valley, 1 Jun 1992, Stone et al. PPI 6851 (L [L.4149526] image seen, PNH); Mt Guiting-guiting, 19 Feb 1994, Reynoso et al. PPI 14069 (L [L.4149619] image seen, PNH). Samar Island: Eastern Samar Prov., Salcedo, Naparaan, 60 m, 16 Apr 2016, Fernando 3925 (LBC); ibidem, 6 Feb 2020, Fernando 4918 (LBC); ibidem, Palanas, 25 m, 7 Feb 2020, Fernando 4927 (LBC). Dinagat Island: Loreto, Malinao, 20 m, 25 Apr 2014, Fernando \& Breganza 3384 (LBC); Balitbiton, 60 m, 31 Aug 2016, Fernando 4143 (LBC); Mt Kambinliw, 134 m, 16 Feb 2016, Lillo 1807 (LBC), Lillo 1830 (LBC); Tubajon, Paragua forest, 132-138 m, 30 Aug 2016, Fernando 4092 (LBC), Fernando 4093 (LBC), Fernando 4096 (LBC); Libjo, Paragua forest, 211 m, 7 Jan 2016, Lillo 013 (LBC); ibidem, 214 m, 11 Jan 2016, Lillo 229 (LBC). Mindanao Island: Agusan del Norte Prov., Butuan, San Mateo, Tungao, 250 m, 1 Jun 1961, Mendoza PNH 41896 (L [L.2390735] image seen, PNH); Surigao del Norte Prov., Claver, Taganito, 300 m, 3 Apr 2011, Fernando 2398 (LBC); Surigao, exact locality not known, 6 Apr 1917, Mallonga FB 27003 (BO, L [L.2390734] image seen).

Notes. Kanis (1968, 1971) mentioned that the species of Brackenridgea sect. Notochnella have a 'yellow' corolla. However, the two taxa placed in this section have corollas that are cream-white (Brackenridgea fascicularis) (Fig. 2C) or white to light pink (B. mindanaensis) (Fig. 4C \& D), never yellow.

Kanis (1968) designated Vidal 1023 as neotype but did not specify the herbarium. As there are at least two specimens of this particular collection, the specimen in $\mathrm{L}$ is designated here as the neotype in a second step neotypification.

2. Brackenridgea foxworthyi (Elmer) Furtado, Gard. Bull. Straits Settlem. 19: 184 (1962). - Ochna foxworthyi Elmer, Leafl. Philipp. Bot. 5: 1823 (1913). - Brackenridgea palustris Bartell. subsp. foxworthyi (Elmer) Kanis, Blumea 16: 48 (1968); Kanis, F1. Males. ser. 1, Spermat. 7: 103 (1971). - TYPE: Philippines, Palawan Island, Puerto Princesa, Mt Pulgar, April 1911, Elmer 13074 (lectotype GH [GH00062713], designated here; isolectotypes A [A00061931], L [L0012452], MO [MO705898], NA [NA0026917], NY [NY00428947], U [U0181272], US [US00110168]). (Fig. 3).

Tree to up to c. $20 \mathrm{~m}$ tall; stem up to c. $20 \mathrm{~cm}$ dbh, rather straight; bark fissured scaly; branches nearly horizontal. Leaves simple, alternately arranged; lamina oblong, $7-10 \times 2-4 \mathrm{~cm}$, base cuneate to obtuse or sometimes rounded, apex obtuse to acute, the margins minutely denticulate or sometimes entire (more distinctly denticulate in juvenile leaves), light green and pendulous; petiole 4-6 mm long. Inflorescences 


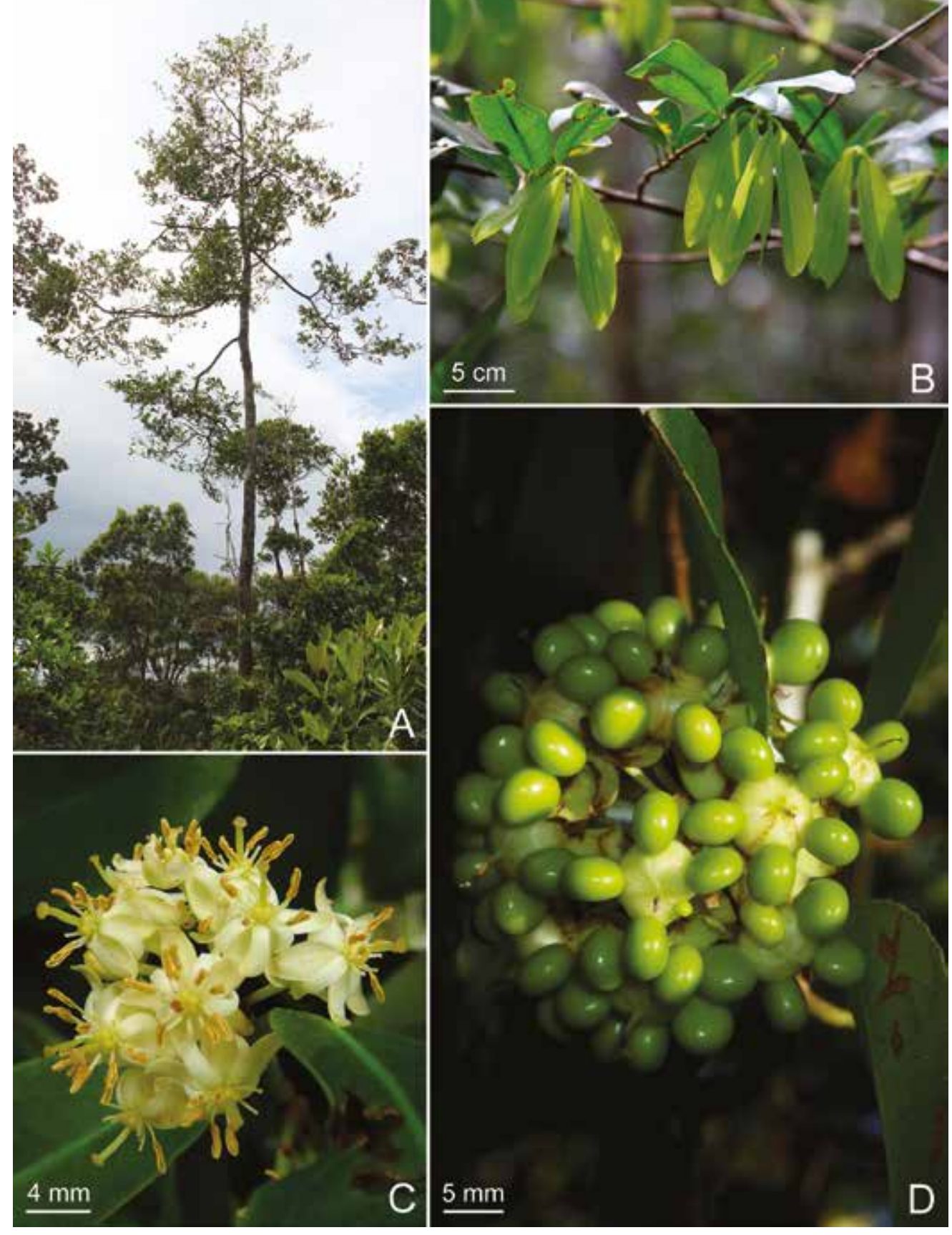

Fig. 3. Brackenridgea foxworthyi (Elmer) Furtado A. Growth habit. B. Leaves, showing seasonal growth, the juvenile ones light green and pendulous. C. Flowers all simultaneously opened. D. Green juvenile fruits. A from Fernando 2360 (LBC); B from Fernando 2355 (LBC); C from Tandang s.n. (PNH); D from Fernando 4802 (LBC). (Photos: A, B, \& D, E.S. Fernando; C, D.N. Tandang). 
terminal, sub-erect, of many, dense-flowered, shortened, sessile cymes, each 1-2 cm long, with 2-3 flowers. Flowers all opening simultaneously, 5-merous, scented; pedicel 1-1.5 cm long; sepals 5, cream-white, subequal, 5-6.5 $\times 2-3 \mathrm{~mm}$; petals light creamwhite, about half as narrower, 5-7 $\times 1.5-2 \mathrm{~mm}$; the sepals and petals often deflexed at anthesis; stamens $10(-12)$, anthers basifixed, 2-3 $\times 0.5 \mathrm{~mm}$, filaments $1.5-2 \mathrm{~mm}$ long, cream-white as the corolla; ovary of 5 separate carpels, smooth and glossy; style 2-2.5 $\mathrm{mm}$ long. Fruit (drupelet) green, ripening red then black, 4-5 × 4-6 mm.

Distribution and ecology. Endemic to the Philippines, Palawan Island. This species is an 'obligate metallophyte' (Lambinon \& Auquier, 1963) or an 'ultramafic obligate' species (Van der Ent et al., 2014), being restricted to ultramafic or metalliferous soils at low elevations. The species has been recorded at $590 \mathrm{~m}$ elevation on Mt Victoria (Podzorski, 1985). It occurs with other plants that are also nickel hyperaccumulators such as Phyllanthus balgooyi Petra Hoffm. \& A.J.M.Baker (Phyllanthaceae) and Walsura monophylla Elmer (Meliaceae) (Proctor et al., 2000; Proctor, 2003; Fernando et al., 2008).

\section{Local name. Bansílai.}

Provisional IUCN conservation assessment. Using GeoCAT (Bachman et al., 2011; http://geocat.kew.org/) an EOO of more than 3,000 $\mathrm{km}^{2}$ and an AOO of $80 \mathrm{~km}^{2}$ were calculated, both of which are within the thresholds for Endangered (EN). The subpopulations of this species are very fragmented. The northern limit of its distribution is on the small coastal Mt Bloomfield, which is now part of a protected area, although previously was subject to chromite mining. The larger southern part of its area of occurrence, on the lower slopes of the Mt Victoria Range and in the Bataraza area are, in part, still subject to surface mining for the heavy metal nickel and also timber poaching for charcoal production that often targets large, mature individuals. These result in a continuing decline in the $\mathrm{AOO}$, extent and quality of the habitat, and the number of locations and subpopulations and of mature individuals of this species. We, therefore, assess this species as Endangered [EN B2ab(ii,iii,iv,v)].

Specimens examined. PHILIPPINES: Palawan Island: Puerto Princesa, Mt Bloomfield, 150 m, 4 May 1984, SMHI 2019 (PNH); ibidem, 184 m, 15 Mar 2018, Fernando \& Barsomo 4575 (LBC); ibidem, Aug-Sep 1986, Reynoso et al. 216 (L [L.2390549]), 274 (L [L.4149497]), images seen, PNH); ibidem, Bacungan, 23 Mar 1947, Edaño PNH 177 (BO, L [L.2390536] image seen, PNH); ibidem, south of Nagtabon Beach, 18 Mar 1990, Soejarto et al. 6859 (L [L.4149465] image seen, PNH); ibidem, 14 May 2011, Tandang s.n. (PNH); ibidem, Magarwak, 55 m, 30 May 2014, Fernando \& Quimado 3425 (LBC, PNH); ibidem, 50 m, 23 Jun 2014, Fernando \& Quimado 3462 (LBC, PNH); ibidem, Mt Beaufort, 230 m, 17 Mar 1984, Podzorski SMHI 547 (PNH); ibidem, 300 m, 21 Mar 1984, Podzorski SMHI 604 (L [L.2390539] image seen, PNH); ibidem, exact locality not known, May 1906, Foxworthy BS 903 (L [L.2390541], US [US03388574], images seen); Narra, San Isidro, Victoria Mountains, 385 m, 18 Mar 2011, Fernando 2353 (LBC), Fernando 2355 (CAHUP, LBC); ibidem, 430 m, 18 Mar 2011, Fernando 2360 (LBC, PNH); ibidem, Bato-Bato River, 65 m, 21 Jun 2014, Fernando 3440 
(CAHUP, LBC); ibidem, 55 m, 22 Jun 2014, Fernando 3454 (LBC, PNH); ibidem, 20 Jun 2019, Fernando 4802 (LBC); ibidem, Trident Mine, 400 m, 19 May 1984, Dransfield SMHI 1272 (L [L.2390598] image seen, PNH); ibidem, Panacan, Karaniogan River, 150 m, 22 May 1950, Sulit PNH 12425 (BO, L [L.2390538] image seen, PNH); ibidem, Urduja, Mariwara, 200 m, 6 Mar 2015, Fernando 3686 (LBC); ibidem, Calategas, 120 m, 20 Jun 2015, Fernando 3780 (LBC); Bataraza, Rio Tuba, 145 m, 17 Aug 2016, Fernando 4051 (LBC, PNH).

Notes. Given the clear physiological, geographical, and habitat differences between Brackenridgea palustris subsp. palustris and B. palustris subsp. foxworthyi discussed earlier (see also Tables 1 and 3), the latter taxon is here elevated to species level. The combination Brackenridgea foxworthyi (Elmer) Furtado has already been made (Furtado, 1962). Elmer (1913) did not indicate a holotype and Kanis (1968) did not specify the lectotype from among the sheets of Elmer 13074; neither did Furtado (1962) when he made the combination. The specimen at GH [GH00062713] is here designated as the lectotype as it is a well-preserved and is a more complete specimen with at least four clusters of flowers. Although this GH specimen was not cited by Kanis (1968), it bears the printed 'Revised for Flora Malesiana' determination label marked 'det. A. Kanis 1967'.

We believe, based on available evidence reported by Kanis (1968) and its apparent restriction to ultramafic soils, that Brackenridgea palustris subsp. kjellbergii is sufficiently distinct from Brackenridgea palustris (sensu stricto) to also be recognised as a distinct species. However, we have had no access to specimens except for digital images of the type (from an ultramafic site), one syntype (from a mangrove swamp), and two more recent collections (from ultramafic sites). This taxon remains poorly known and requires further study. We refrain from making the combination at this time.

3. Brackenridgea mindanaensis (Merr.) Fernando, comb.nov.-Ouratea mindanaensis Merr., Philipp. J. Sci. 17: 287 (1920). - Brackenridgea fascicularis (Blanco) Fern.-Vill. subsp. mindanaensis (Merr.) Kanis, Blumea 16: 44 (1968); Kanis, Fl. Males. ser. 1, Spermat. 7: 104 (1971). - TYPE: Philippines, Mindanao Island, Surigao Prov., locality not known, 'along streams at low altitudes at the iron deposits on the northeast coast', April 1919, Ramos \& Pascasio BS 34479 (lectotype A [A00062720], designated here; isolectotypes K [K000657987], L [L0012442], P [P01817426], US [US00110174]). (Fig. 4).

Small tree 2-4(-5) m tall; stem 2-3(-5) cm dbh; crown lax, branches slender. Leaves simple, alternately arranged; lamina oblong-elliptic to lanceolate, coriaceous, (4-)7$9(-11) \times(1.5-) 2-3(-4) \mathrm{cm}$, base cuneate to rounded, apex acute to acuminate, the margins denticulate; petiole 2.5-5 $\mathrm{mm}$ long. Inflorescences terminal or subterminal, sub-erect or pendulous, consisting of 2- or 3-, or sometimes 4-peduncled, umbel-like cymes, few-flowered; peduncles 5-10(-18) mm long. Flowers opening successively, 4-merous; pedicel (7-)10-13 mm long; sepals broadly-elliptic, boat-shaped, 3-4 × 
Table 3. Characters distinguishing Brackenridgea foxworthyi from Brackenridgea palustris (sensu stricto).

\begin{tabular}{|c|c|c|c|}
\hline & $\begin{array}{l}\text { Brackenridgea } \\
\text { foxworthyi }\end{array}$ & $\begin{array}{l}\text { Brackenridgea } \\
\text { palustris }\end{array}$ & Reference source \\
\hline Habitat & $\begin{array}{l}\text { Restricted to forests on } \\
\text { ultramafic soils, up to } \\
590 \text { m elevation }\end{array}$ & $\begin{array}{l}\text { Mainly on marshy, peat } \\
\text { swamp, or lowland and } \\
\text { montane forests up to } \\
1200 \text { m elevation }\end{array}$ & $\begin{array}{l}\text { Podzorski, 1985; } \\
\text { Niyomdham, } \\
\text { 1986; } \\
\text { Kochummen, } \\
\text { 1995; Proctor, } \\
\text { 2003; Phoon, } \\
\text { 2012; this study }\end{array}$ \\
\hline Growth habit & $\begin{array}{l}\text { Small to medium sized } \\
\text { tree up to c. } 20 \mathrm{~m} \text { tall; } \\
\text { stem } 20 \mathrm{~cm} \text { dbh; outer } \\
\text { bark fissured-scaly }\end{array}$ & $\begin{array}{l}\text { Medium to large tree } \\
\text { up to c. } 30 \mathrm{~m} \text { tall; stem } \\
40-120 \mathrm{~cm} \text { dbh; outer } \\
\text { bark smooth to scaly }\end{array}$ & $\begin{array}{l}\text { Elmer, 1913; } \\
\text { Kochummen, } \\
\text { 1995; Phoon, } \\
\text { 2012; this study }\end{array}$ \\
\hline $\begin{array}{l}\text { Foliar nickel } \\
\text { hyperaccumulation } \\
\left(\mu \mathrm{g} \mathrm{g}^{-1} \text { leaf dry matter) }\right.\end{array}$ & $2671-7600$ & $1-14$ & $\begin{array}{l}\text { Baker et al., 1992; } \\
\text { this study }\end{array}$ \\
\hline $\begin{array}{l}\text { Geographic } \\
\text { distribution }\end{array}$ & Palawan (Philippines) & $\begin{array}{l}\text { S. Thailand, Malay } \\
\text { Peninsula, Singapore, } \\
\text { Sumatra, Borneo }\end{array}$ & $\begin{array}{l}\text { Kanis, 1968, } \\
\text { 1970, 1971; } \\
\text { Niyomdham } \\
\text { 1986; this study }\end{array}$ \\
\hline
\end{tabular}

2.5-3 mm, pink, turning red in fruit; petals oblong-elliptic, 5-7 $\times 2-3 \mathrm{~mm}$, white to light pink; stamens $8(-10)$; anthers basifixed, 2-2.5 $\times 1 \mathrm{~mm}$ wide, filaments $1.0-1.5$ $\mathrm{mm}$ long, pale white; ovary of 5 separate carpels, smooth and glossy, style $5 \mathrm{~mm}$ long. Fruit (drupelet) pinkish when young, ripening red, then glossy black, 4-6 $\times 4-5 \mathrm{~mm}$.

Distribution and ecology. Endemic to the Philippines, Mindanao Island. Restricted to forests on ultramafic soils at low elevations up to $60 \mathrm{~m}$, often along rivers or creeks. This species is an 'obligate metallophyte' following the classification of Lambinon \& Auquier (1963) or ‘ultramafic obligate’ following Van der Ent et al. (2014).

\section{Local names. Pagbalikan, pinúlug.}

Provisional IUCN conservation assessment. Using GeoCAT (Bachman et al., 2011; http://geocat.kew.org/), an EOO of $34.82 \mathrm{~km}^{2}$ was calculated, which is well within the threshold for Critically Endangered (CR). The AOO was estimated at $24.00 \mathrm{~km}^{2}$, which is within the threshold for Endangered (EN) (IUCN, 2012; IUCN Standards and Petitions Subcommittee, 2017). This species has a severely fragmented population; more than half of the populations are in small patches of only a few individuals. Over almost a decade of field visits to the area, we have observed a steady decline in the extent of occurrence, area of occupancy, the area, extent and quality of the habitat, and 

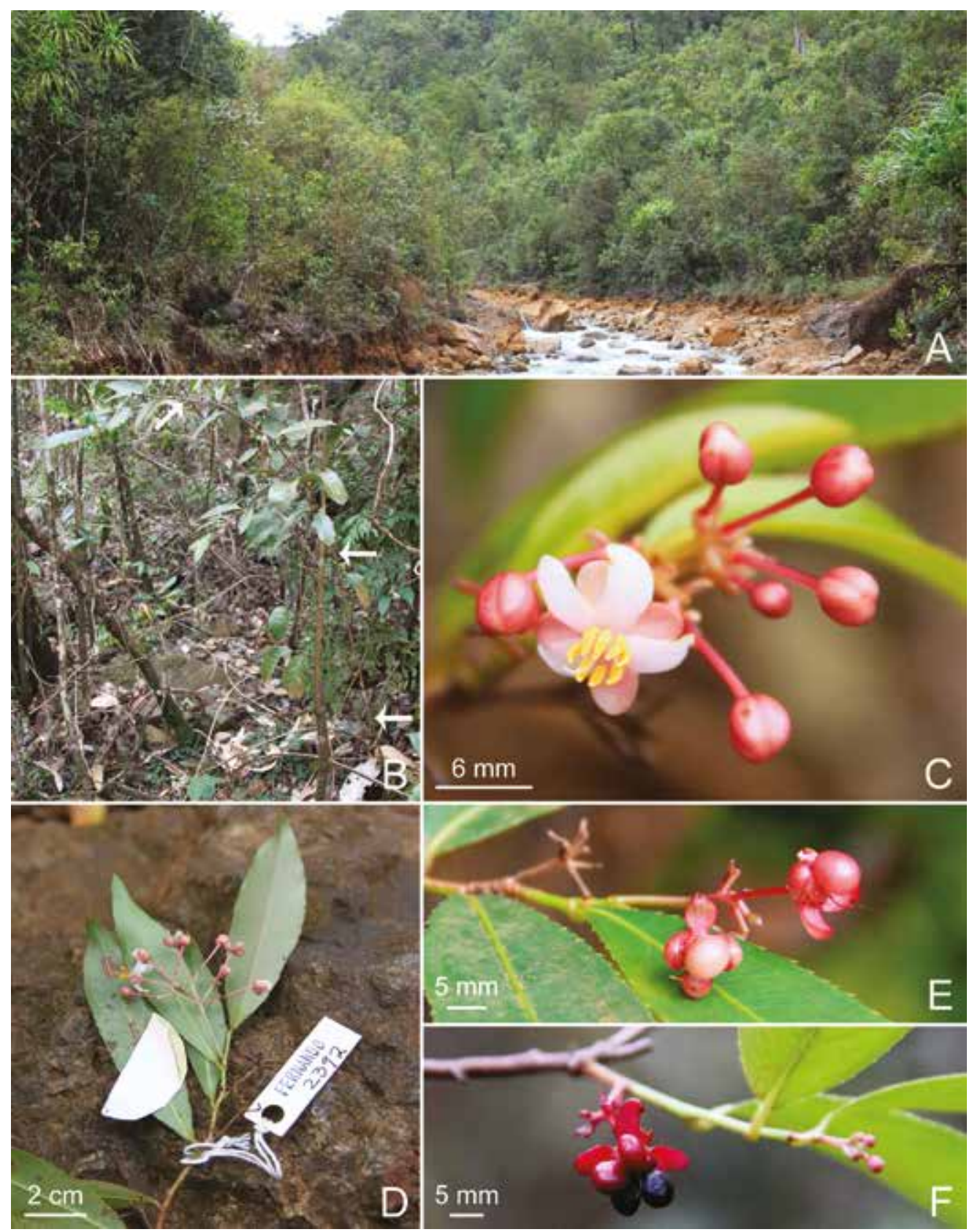

Fig. 4. Brackenridgea mindanaensis (Merr.) Fernando A. Habitat at c. $30 \mathrm{~m}$ elevation in Claver, Surigao del Norte Prov., Mindanao, Philippines. B. Growth habit showing lax crown; arrows show the actual plant $\mathbf{C}$. Flower buds and open flower showing eight anthers and four pinkish petals and four sepals. D. Twig with leaves showing denticulate margins and inflorescence showing cymes with distinct peduncles and flowers with long pedicels. E. Pinkish juvenile fruits with four, persistent pink sepals. F. Ripe, blackish fruits with red calyx and torus. B, C, \& E from Fernando 2392 (LBC); D from Fernando 2395 (LBC); F from Fernando 3230 (LBC). (Photos: E.S. Fernando). 
number of locations or subpopulations. All known localities of this species are subject to open surface mining for nickel. We, therefore, assess this species as Critically Endangered [CR B1ab(i,ii,iii,iv)].

Specimens examined. PHILIPPINES: Mindanao Island: Surigao del Norte Prov., Claver, Taganito, 30 m, along creek, 3 Apr 2011, Fernando 2392 (LBC, PNH), Fernando 2395 (LBC, PUH); ibidem, 60 m, 8 Aug 2013, Fernando 3230 (LBC, PNH); ibidem, 55 m, rocky slope near stream, 29 Apr 2015, Fernando 3764 (CAHUP, LBC), Obasan River, 60 m, 2 Feb 2013, Fernando 3139 (LBC, PNH).

Notes. Merrill (1920) recorded 3-4 sepals, 3-4 petals, and 8-10 stamens in this species. The flower colour was not known by Merrill (1920), but he noted its similarity to Ochna fascicularis Blanco. Kanis (1968) also did not have information on flower colour, but recognised 'strong reductions in calyx, corolla, and androecium'. He noted that he found ' 3 or 4 sepals per flower', which according to him, 'is probably due to the connation between 1 or 2 pairs of the original 5 ...' and that 'the same might be the case in the corolla judging from Merrill's description'. Kanis (1968: 45) stated that 'this is only an occasional deviation with little or no taxonomical importance.' However, all our recent collections of this species from the area of its type locality consistently had four sepals and four petals with distinctly white to light pinkish corollas (Fig. 4C \& D). The leaves are also frequently and distinctly denticulate (Fig. 4C, E \& F), even when mature. Two specimens from Mindanao cited by Kanis (1968) under this species clearly belong to Brackenridgea fascicularis.

Brackenridgea mindanaensis is mainly a small tree with a lax crown (Fig. 4B). It is further distinguished from Brackenridgea fascicularis in its prominently denticulate leaves, fewer-flowered cymes with longer peduncles (up to $2 \mathrm{~cm}$ long), smaller, white or light pinkish and 4-merous flowers, and pinkish juvenile fruits (Fig. 4C-E). Given the ample differences between the two taxa (see also Table 4), this taxon is here regarded as a distinct species and the new combination Brackenridgea mindanaensis (Merr.) Fernando is made. This is a very rare species and is restricted to low elevations on ultramafic soils on the northeastern area of Mindanao.

ACKNOWLEDGEMENTS. This study was part of the Program on the Rehabilitation and Restoration of Mining Areas through Phytotechnologies funded by the Department of Science and Technology - Philippine Council for Industry, Energy, and Emerging Technology Research and Development (DOST-PCIEERD). The permit to collect plant specimens for scientific research study was covered by the Gratuitous Permit Nos. 199, 211, 231, and R13-2015-006 issued by the Department of Environment and Natural Resources (DENR) of the Philippines, and Gratuitous Permit Nos. 2014-10, 2016-27, and 2018-15 issued by the Palawan Council for Sustainable Development (PCSD). We thank the Provincial Environment and Natural Resources Office (PENRO-DENR) of Dinagat Island for logistical support for field work. The Taganito Mining Corporation and Rio Tuba Mining Corporation; and Narra Nickel Mining Corporation are all gratefully acknowledged for allowing us access to their mining concessions and for help with providing on-site transport logistics. Two anonymous reviewers provided very useful comments on an earlier version of this manuscript. 
Table 4. Characters distinguishing Brackenridgea fascicularis from Brackenridgea mindanaensis.

\begin{tabular}{|c|c|c|}
\hline & Brackenridgea fascicularis & Brackenridgea mindanaensis \\
\hline Habitat & $\begin{array}{l}\text { Occurs on both ultramafic and non- } \\
\text { ultramafic soils, up to } 850 \mathrm{~m} \\
\text { elevation }\end{array}$ & $\begin{array}{l}\text { Restricted to ultramafic soils, low } \\
\text { elevations up to } 60 \mathrm{~m}\end{array}$ \\
\hline Growth habit & $\begin{array}{l}\text { Medium-sized tree, } 6-18 \mathrm{~m} \text { tall or } \\
\text { more, stem } 10-30 \mathrm{~cm} \mathrm{dbh} \text {; dense } \\
\text { crown }\end{array}$ & $\begin{array}{l}\text { Small tree, } 2-4 \mathrm{~m} \text { tall; stem to } 2-3 \\
\mathrm{~cm} \text { dbh; lax crown }\end{array}$ \\
\hline Leaves & $\begin{array}{l}\text { Elliptic, }(7-) 10-13(-17) \mathrm{cm} \times(2- \\
) 3-4(-5) \mathrm{cm} \text {, margins generally } \\
\text { entire, only very rarely partially } \\
\text { denticulate }\end{array}$ & $\begin{array}{l}\text { Oblong-elliptic to lanceolate, }(4-) 7- \\
9(-11) \mathrm{cm} \times(1.5-) 2-3(-4) \mathrm{cm} ; \\
\text { margins always distinctly } \\
\text { denticulate }\end{array}$ \\
\hline Inflorescence & $\begin{array}{l}\text { Up to } 15 \text {-flowered; rachis } 1-2.5 \mathrm{~cm} \\
\text { long; cyme peduncle } 2-5 \mathrm{~mm} \text { long }\end{array}$ & $\begin{array}{l}\text { Up to } 7 \text {-flowered; rachis } 2-6 \mathrm{~cm} \\
\text { long; cyme peduncle } 5-10(-18) \mathrm{mm} \\
\text { long }\end{array}$ \\
\hline Flower & $\begin{array}{l}\text { Sepals } 5 \text {; petals } 5 \text {, cream-white; } \\
\text { stamens } 20(-45) \text {; ovary of } 8-10 \\
\text { carpels }\end{array}$ & $\begin{array}{l}\text { Sepals } 4 \text {; petals } 4 \text {, light pink; } \\
\text { stamens } 8(-10) \text {; ovary of } 5 \text { carpels }\end{array}$ \\
\hline Fruit & $\begin{array}{l}\text { Green when young, ripening red } \\
\text { then glossy black }\end{array}$ & $\begin{array}{l}\text { Pink when young, ripening red then } \\
\text { glossy black }\end{array}$ \\
\hline $\begin{array}{l}\text { Geographic } \\
\text { distribution }\end{array}$ & $\begin{array}{l}\text { Luzon, Polillo, Catanduanes, } \\
\text { Sibuyan, Samar, Dinagat, } \\
\text { Mindanao }\end{array}$ & Mindanao \\
\hline
\end{tabular}

\section{References}

Ata, J.P., Luna, A.C., Tinio, C.E., Quimado, M.O., Maldia, L.S., Abasolo, W.P. \& Fernando, E.S. (2016). Rapid assessment of plant diversity in ultramafic soil environments in Zambales and Surigao del Norte, Philippines. Asian J. Biodivers. 7: 1-16.

Bachman, S., Moat, J., Hill, A.W., de la Torre, J. \& Scott, B. (2011). Supporting Red List threat assessments with GeoCAT: geospatial conservation assessment tool. ZooKeys 150: $117-126$.

Baker, A.J.M., Proctor, J., Van Balgooy, M.M.J. \& Reeves, R.D. (1992). Hyperaccumulation of nickel by the flora of the ultramafics of Palawan, Republic of the Philippines. In: Baker, A.J.M., Proctor, J. \& Reeves, R.D. (eds) The Vegetation of Ultramafic (Serpentine) Soils: Proceedings of the First International Conference on Serpentine Ecology, pp. 291-304. Andover, U.K.: Intercept Ltd.

Brooks, R.R., Lee, J., Reeves, R.D. \& Jaffré, T. (1977). Detection of nickeliferous rocks by analysis of herbarium specimens of indicator plants. J. Geochem. Explor. 7: 49-57.

Callmander, M.W., Buerki, S. \& Phillipson, P.B. (2010). The genus Brackenridgea A.Gray (Ochnaceae) in Madagascar. Candollea 65: 374-375.

Elmer, A.D.E. (1913). Four score of new plants. Leafl. Philipp. Bot. 5: 1751-1853. 
Fernando, E.S., Suh, M.H., Lee, J. \& Lee, D.K. (2008). Forest Formations of the Philippines. Seoul: Seoul National University, ASEAN-Korea Environmental Cooperation Unit.

Fernando, E.S., Quimado, M.O., Trinidad, L.C. \& Doronila, A.I. (2013). The potential use of indigenous nickel hyperaccumulators for small-scale mining in the Philippines. $J$. Degraded Mining Lands Managem. 1(1): 21-26.

Fernando, E.S., Quimado, M.O. \& Doronila, A.I. (2014). Rinorea niccolifera (Violaceae), a new, nickel-hyperaccumulating species from Luzon Island, Philippines. PhytoKeys 37: $1-13$.

Furtado, C.X. (1962). The species of Brackenridgea in the Singapore Herbarium. Gard. Bull. Straits Settlem. 19: 181-184.

Galey, M.L., Van der Ent, A., Iqbal, M.C.M. \& Rajakaruna, N. (2017). Ultramafic geology of South and Southeast Asia. Bot. Stud. 58: 18.

Gotera, K.C., Doronila, A.I., Claveria, R.J.R., Perez, T.R, Unson, J.R.S., Penaranda, M.C.R., Sebastian, M.B. \& Medina, J.C.S. (2014). Breynia cernua (Poir.) Müll.Arg. (Phyllanthaceae) is a hyperaccumulator of nickel. Asia Life Sci. 23(1): 231-241.

Hoffmann, P., Baker, A.J.M., Madulid, D.A. \& Proctor, J. (2003). Phyllanthus balgooyi (Euphorbiaceae s.1.), a new nickel-hyperaccumulating species from Palawan and Sabah. Blumea 48: 193-199.

IUCN (2012). IUCN Red List Categories and Criteria. Version 3.1, 2nd edition. Gland, Switzerland and Cambridge, U.K.: IUCN.

IUCN Standards and Petitions Subcommittee (2017). Guidelines for Using the IUCN Red List Categories and Criteria. Version 13. Prepared by the Standards and Petitions Subcommittee.

Kanis, A. (1968). A revision of the Ochnaceae of the Indo-Pacific area. Blumea 16: 1-82.

Kanis, A. (1970). Ochnaceae. In: Smitinand, T. \& Larsen, K. (eds) Flora of Thailand, vol. 2, pt. 1, pp. 24-30. Bangkok: The Forest Herbarium, Royal Forest Department.

Kanis, A. (1971). Ochnaceae. In: van Steenis, C.G.G.J. (ed.) Flora Malesiana, ser. 1, Seed Plants, vol. 7, pt. 1, pp. 97-119. Leiden: Noordhoff.

Kochummen, K.M. (1995). Ochnaceae. In: Soepadmo, E. \& Wong, K.M. (eds.) Tree Flora of Sabah and Sarawak, vol. 1, pp. 257-270. Kuala Lumpur: Forest Research Institute Malaysia, Sabah Forestry Department and Sarawak Forestry Department.

Lambinon, J. \& Auquier, P. (1963). La flore et la végétation des terrains calaminaires de la Wallonie septentrionale et de la Rhénanie Aixoise: Types chorologiques et groupes écologiques. Nat. Mosana 16: 113-131.

Merrill, E.D. (1920). New or noteworthy Philippine plants, XVI. Philipp. J. Sci. 17(3): 239323.

Niyomdham, C. (1986). A list of flowering plants in the swamp area of Peninsular Thailand. Thai Forest Bull. 16: 211-229.

Pelser, P.B., Barcelona, J.F. \& Nickrent, D.L. (eds) (2011 onwards). Co's Digital Flora of the Philippines. http://www.philippineplants.org. Accessed 14 Dec. 2019.

Phoon, S.N. (2012). Ochnaceae. In: Kiew, R., Chung, R.C.K., Saw, L.G. \& Soepadmo, E. (eds) Flora of Peninsular Malaysia, ser. 2, vol. 3, pp. 277-298. Malayan Forest Records No. 49. Kepong: Forest Research Institute Malaysia.

Podzorski, A.C. (1985). The Palawan Botanical Expedition Final Report. Landskrona, Sweden: Hilleshög Forestry AB.

Proctor, J. (1992). The vegetation over ultramafic rocks in the tropical Far East. In: Roberts, B.A. \& Proctor, J. (eds) The Ecology of Areas with Serpentinized Rocks: A World View, pp. 249-270. Dordrecht: Kluwer. 
Proctor, J. (2003). Vegetation and soil and plant chemistry on ultramafic rocks in the tropical Far East. Perspect. Pl. Ecol. Evol. Syst. 6(1, 2): 105-124.

Proctor, J., Baker, A.J.M., Van Balgooy, M.M.J., Bruijnzeel, L.A., Jones, S.H. \& Madulid, D.A. (2000). Mount Bloomfield, Palawan, Philippines: Forests on greywacke and serpentinized peridotite. Edinburgh J. Bot. 57: 121-139.

Quimado, M.O., Fernando, E.S., Trinidad, L.C. \& Doronila, A.I. (2015). Nickel hyperaccumulation in species of Phyllanthus (Phyllanthaceae) from the Philippines. Austral. J. Bot. 63: 103-110.

Reeves, R.D. (1992). Hyperaccumulation of nickel by serpentine plants. In: Baker, A.J.M., Proctor, J. \& Reeves, R.D. (eds) The Vegetation of Ultramafic (Serpentine) Soils: Proceedings of the First International Conference on Serpentine Ecology, pp. 253-277. Andover, U.K.: Intercept Ltd.

Reeves, R.D., Baker, A.J.M., Borhidi, A. \& Berazaín, R. (1996). Nickel-accumulating plants from the ancient serpentine soils of Cuba. New Phytol. 133: 217-224.

Reeves, R.D., Baker, A.J.M., Borhidi, A. \& Berazaín, R. (1999). Nickel hyperaccumulation in the serpentine flora of Cuba. Ann. Bot. 83: 29-38.

Reeves, R.D., Baker, A.J.M., Jaffré, T., Erskine, P.D., Echevarria, G. \& Van der Ent, A. (2017). A global database of plants that hyperaccumulate metal and metalloid trace elements. New Phytol. 2018: 407-411.

Schatz, G.E. (2001). Generic Tree Flora of Madagascar. Kew: Royal Botanic Gardens, Kew; and St Louis: Missouri Botanical Garden.

Schneider, J.V., Bissiengou, P., Maria do Carmo, E.A., Tahir, A., Fay, M.F., Thines, M., Sosef, M.S.F., Zizka, G. \& Chatrou, L.W. (2014). Phylogenetics, ancestral state reconstruction, and a new infrafamilial classification of the pantropical Ochnaceae (Medusagynaceae, Ochnaceae s. str., Quiinaceae) based on five DNA regions. Molec. Phylogen. Evol. 78: 199-214.

Soejarto, D.D. (1989). Plant collecting in Palawan. Bull. Field Mus. Nat. Hist. 60(5): 24-28.

Soejarto, D.D., Gyllenhaal, C., Ashton, P.S. \& Sohmer, S.H. (1996). Plant explorations in Asia under the sponsorship of the National Cancer Institute, 1986-1991: An overview. In: Balick, M.J., Elisabetsky, E. \& Laird, S.A. (eds) Medicinal Plant Resources of the Tropical Forest, pp. 284-310. New York: Columbia University Press.

Sohmer, S.H. (1996). The urgency of documenting plant diversity: The Flora of the Philippines Project - a last chance to study the plant diversity of the Philippines. In: Stuessy, T.F. \& Sohmer, S.H. (eds) Sampling the Green World, pp. 28-40. New York: Columbia University Press.

Stone, B.C. (1991). Expeditions and other field work - Philippines. Fl. Males. Bull. 10(4): 314-315.

Van derEnt,A., Baker,A.J.M., Reeves, R.D., Pollard,A.J. \& Schat, H.(2012). Hyperaccumulators of metal and metalloid trace elements: Facts and fiction. Plant Soil 362(1-2): 319-334.

Van der Ent, A., Repin, R., Sugau, J. \& Wong, K.M. (2014). The Ultramafic Flora of Sabah: An Introduction to the Plant Diversity on Ultramafic Soils. Kota Kinabalu, Malaysia: Sabah Parks and Natural History Publications (Borneo) Sdn. Bhd.

Yumul, G.P. Jr., Dimalanta, C.B., Maglambayan, V.B. \& Tamayo, R.A. Jr. (2003). Mineralization controls in island arc settings: Insights from Philippine metallic deposits. Gondwana Res. 6(4): 767-776. 
